\title{
Representation of 2004 General Election Campaign in Comics Media: Semiotics studies of Comic Ketopraktoon in the 2004 Election Campaign in Kompas Newspaper
}

\author{
Dr. Bertha Sri Eko Murtiningsih
}

Multimedia Nusantara University, Tangerang, Indonesia

Doi: $10.1515 / m j s s-2017-0030$

\begin{abstract}
Comic could be a means to represent certain values. The reality is described through the storyline, setting and characterization which are packed in comic rubric. In comic, the whole symbols in the text will give certain meanings. They are including characters, dialogues, words written in word balloons, figure characters, and setting. This combination formed certain meanings which will determine how the reality will be framed by the media.Ketopraktoon is a comic strip which consistently reviews the sociopolitical issues and serves as a semi-comic in Kompas newspaper editorial. The strength of ketopraktoon in its social critics is built of figure's characters which are presented in straightforward way with the support of storyline which fitted to the actual and factual condition in accordance with the dynamics of general election in Indonesia. This study aimed to discover how the election campaign during the Reform Era is represented in Ketopraktoon comic. This study used a qualitative approach with data analysis techniques semiotics of Barthes. To find the signs require appropriate and feasible methods of text analysis. Since the text to analyze is in the form of comics, the researcher defines the sign found in the comic text applies the technique that uses the semiotics of Barthes connotations and myths. The results showed (1) General Election campaign purely contained slogans and political rhetoric; (2) Pragmatism political parties and constituency campaign; (3) Irrationality behavior of political parties and constituency campaign; (4) Political branding refers to a materialistic tradition to gain popularity and power; (5) primitive and traditional culture in the election campaign.
\end{abstract}

Keywords : Election, Campaign, Comic, Representation, Ketopraktoon, Kompas Newspaper

\section{Research Background}

Media is a means of representation of certain values. Through various features it presents, certain reality is presented to the public. Although the reality is symbolic, but in fact the reality is often regarded as a truth and legitimacy of certain values.

As suggested by Fourie (2008, p. Xxv), the media plays an important role in the process of representation. History of the media and how the media is related to the structures in society such as politics, economy and culture frequently show tendency to portray, people, groups, and organizations structurally and is linked to stereotypes, as well as ideological, which is symbolic power of the media.

Representation refers to the use of language and images to create meaning about the world around us. What is shown by the media through the language and symbols is used by the media to describe and understand the world we see (Sturken and Cartwright, 2001, p. 12). Media helps to represent the world and helps people to understand the reality often shown by media, regarded as a truth. Representations are often ideological. Media tends to give a view that is partial and 
selective about the reality of certain groups in order to maintain power.

Comics is one section in the printed media which has certain uniqueness. Comics can be a means of representation of certain values. Through the storyline, setting, and characterization packed within the rubric of the comic, depicted reality can be figured out. In the comics media, all symbols in its text will give certain meanings. Symbols in comics include characters, figures' dialogue, word balloons, and setting. This combination forms specific meanings which will determine how the reality will be framed by the media. Images symbolization in comics can be used to express the intention and purpose through gestures, facial expressions, and dialogue.

McCloud (2001, p. 9) stated that the comic is present in the form of images and language and used to express something. It shows that in comic text communication events are reflected. In the context of comic communication, comic is a medium or a means of messages, which has different values in the communication of news, feature and other forms of communication in the media, especially newspapers. Communication differences are due to the way of packing more oriented comic pictures and symbols arranged in a position in a specific order, functioning to convey information and /or achieve aesthetic responses from readers.

Ketopraktoon comic highlighted and criticized events which occur in Indonesian general elections, especially in the year of 2004. Election events raised by the comic Ketopraktoon are including, but not limited to, the election campaign, the behavior of the political elite figures, political imagery and a coalition of political parties, etc.

General Election (Pemilu) is an integral part of the democratic process associated with the constitutional change of power in the organization of national and state life. Election becomes a major signal whether a nation is able to uphold and implement democratic values in full accordance with the constitutional mandate. In that context, since the Reformation Era, Indonesia has been able to carry out democratic general elections for four times (1999, 2004, 2009 and 2014) in line with the constitutional mandate.

Campaign becomes an important part in the elections because through these activities the candidates can express the vision and mission of the candidates program. The election campaign is regulated by laws related to materials, techniques and sanctions for violations of the campaign.

Campaign preceding the general elections in Indonesia is an interesting phenomenon. The election campaign uses many language jargons, labeling, metaphors and euphemisms. In the general election campaign the candidates have not expressed working programs measurably and transparently. The candidates have pleased promises to their constituents with empty promises. Generally, more importantly for the contestants is to gain the most votes and win.

The author once personally interviewed, Arbi Sanit, a senior political analyst and prominent Indonesian political scientist, back in April 17, 2013. He stated that messages conveyed by the election campaign constituents are hyperbolic and utopian. The rise of political jargons is inseparable from Indonesian culture that likes to listen to fairy tales and nice oral stories. Campaign is a story because what is said in the campaign often illogical and unreal.

This research will analyze the representation of election campaign in Indonesia through the comic published in Kompas. Kompas daily is one of the largest credible and independent printed media in Indonesia. It is one of the largest national newspapers with a circulation of achieving the average of 500,000 copies per day, as well as having the reader of the upper middle class kind of level of education and socioeconomic status.

This research chose rubric comic Ketopraktoon as the research object, because (1) the comic contains specifically the 2004 elections in Indonesia; (2) it is one of the products of journalism: comic strip Ketopraktoon consistently highlighted the social and political issues currently emerged in national scope, with humorous and critical standpoint.

This research employed a qualitative approach with method of Roland Barthes' semiotics. Semiotic study is concerned with how meaning is created and delivered through text and especially through the narrative. The semiotics' focus of attention is signs' interplay found in the text. The signs can be understood as a combination of signifier and signified. 


\section{Theoretical Perspective}

\subsection{Ketopraktoon as Comic Genre}

Nurgiyantoro (2004, p.110) once refers to the work of Lukens, Smith, and Coffel (2013), saying that genre is a literary type having a set of common characteristics. Genre definition refers to the grouping of literary works category which is usually based on the style, form or content. It means that genre is a literary work and there are elements of similar properties. Elements in a genre are different from the elements contained in other genres. For example, in the comic genre there are different elements to the genre of caricature. Structural elements in the genre show differences and existence of each. Understanding the genre difference is significant to see a cultural product because genre analysis will ease the discussion on cultural products, such as comics.

Ketopraktoon features can be categorized as a genre, since Ketopraktoon rubric contains elements like narrative, story setting, characters, style, visual and aural signs as well as typical methods of delivery. Ketopraktoon section belongs to comic genre rather comic strip.

According to Pujiyanto (2008, pp.144-148), comic strip is a serial published in the daily mass media or newspapers. Comics have a visual language to maximize the power of expressions or word through the embodiment of the image and minimize the dialog text that helps penetrate comic reader. Comic strips have characteristics namely, (1) a permanent character with a funny realist style or shape; (2) the frame is used to indicate the action; (3) facial expressions as emotional expression or character; (4) bubble.

Ajidarma (2011, p. 40) affirms not only does the bracketing of the letters of speech in a line with a bubble show who is speaking, but also the meaning contributing the narrative. The spoken voice character is shown by how the lines are shutting the expression made. Letters writing contained in the word balloon represents the character and emotion of speech, to demonstrate the character of the speaker. A wide variety of meanings emerge from writing letters, from noise level up to a character. Word balloons also show comic dialogue.

Ketopraktoon Comic strip has fixed (recurrent) or not fixed (temporary) character. Fixed characters are Pailul, Koming, Ni Dyah Gembili, Ni Woro Ciblon, Empu Randu Bantal, Aryakendor, and Bujel and Trinil. The temporary characters are the leaders and politicians. The characters include protagonist and antagonist. The role of a character in a comic is very crucial. Character can be manifested into a protagonist (hero or main actors are good) or antagonist (an opponent protagonist, malicious actors can shape a person or something that is against goodness). A protagonist does not have to be displayed in a nice-looking figure, as well as the antagonist is not always ugly. However, the decisive factor is the "language of the soul" of the character which is reflected in the words and behavior (Koendoro, 2008, p. 101).

On the story, comic can be divided into fiction and non-fiction. Sastriyani $(2004, p .123)$, suggested that a fictional comic contains fantasy and it never exists and occurs factually. This comic relies on the strength of the author's imagination. Meanwhile, the non-fictional comic is a comic that tells something that exists and occurs in the history and also factual. Ketopraktoon is categorized as non-fictional comic conveying factual and actual events happening in the community. Ketopraktoon comic tells a lot about the events related to current social and political issues.

\subsection{Concept of Representation}

Media is able to represent reality or even perform it, so that it can be said that representation contains "a second meaning". As Fourie (2008: xxv) stated, the media plays an important role in the process of representation.

"The history of media and media's relationship with structures in society such as politics, the economy and culture, has shown over and again. Media tends to portray people, groups, organization and topics in structured, stereotyped and often in ideologically predisposed ways. This constitutes the media symbolic power. The concept of representation is thus of the most importance for our critical understanding of how media works. 
The above concept implies that the history of the media and how the media relations with the structures in society such as politics, economy, and culture frequently shows that it tends to portray people, groups, organizations and topics structurally and linked to stereotype and often ideological which is a strong symbolic media. The concept of representation is significant to critically understand how the media works.

The concept of representation is reinforced by Hall (1997, pp. 15-24),

Representation means using language to say something meaningful about, or to represent the world meaningfully, to other people. Representation is an essential part of the process by which meaning is produced and exchanged between members of culture. It involves the use of language, signs and images which stand for or represent things

The above concept implies that the representation is an important part of the process in which meaning is exchanged and produced by members of a particular culture. It includes the use of language, the signs, and the image that represent something.

Meanings generated by individuals are part of the representation. Media helps represent the world and helps people to understand the reality. Reality is often considered a truth. Representation in the media is not only related to what is shown by the media, but also to the meaning built behind the media. Media texts are constructed and it presents the world reality. Representations are often ideological; they tend to provide partial and selective view of reality in order to maintain the power of certain groups.

\section{Aims of Study and Research Method}

Research on the comic must be done thoroughly and cannot be partial. The problem viewed in this study is a unity of event, time, culture and texts form the reality of political communication. The reality of political communication in the comic text must be understood and interpreted in depth of component symbols in the form of a text which is the object of research. In exposing the reality of the comic text and the reader understanding of reality, this study applies qualitative research.

The object of study in this research is the comic section Ketopraktoon published in Kompas in 2004. The research is focused on the context of how the representation of the 2004 election campaign as it is shown in the comic section Ketopraktoon in Kompas

To find the signs requires appropriate and feasible methods of text analysis. Since the text to analyze is in the form of comics, the researcher defines the sign found in the comic text applies the technique that uses the semiotics of Barthes' connotations and myths.

Barthes signification structure can be described as follows:

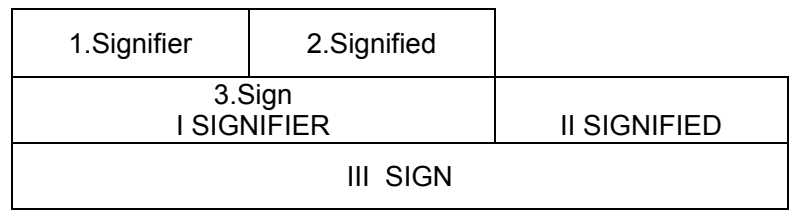

Figure 1.1. Myth scheme in Second level Signification

Source: Barthes (1972, p. 115)

Kaelan (2009, p. 200-201), voicing Barthes' idea, has its own conventions associated with the code. The codes include: (1) the hermeneutic code or code puzzles ranging in the hope the reader to get the truth to the questions that appear in the text. Code puzzle is a major structural element in the traditional narrative; (2) the semic code or connotative, in the process of reading, the reader composes the theme of a text. Connotations of certain words in the text can be grouped with the connotation of the word or phrase that is similar. If the number of connotations are related to a particular name, we can recognize the characters in a particular attribute; (3) the symbolic code, the structural coding aspects of fiction, in the words of Barthes, post structural. It is based on the idea 
that the meaning comes from some binary opposition, in the level of sound into phonemes in speech production process. In a verbal text, symbolic resistance can be encoded by terms such rhetorical antithesis; (4) the proairetic code code or action code which is the main equipment of text; (5) the gnomik code or cultural code which is a text reference to objects known and codified by the culture.

\section{Results}

\subsection{Election Campaign in Ketopraktoon Comic Feature}

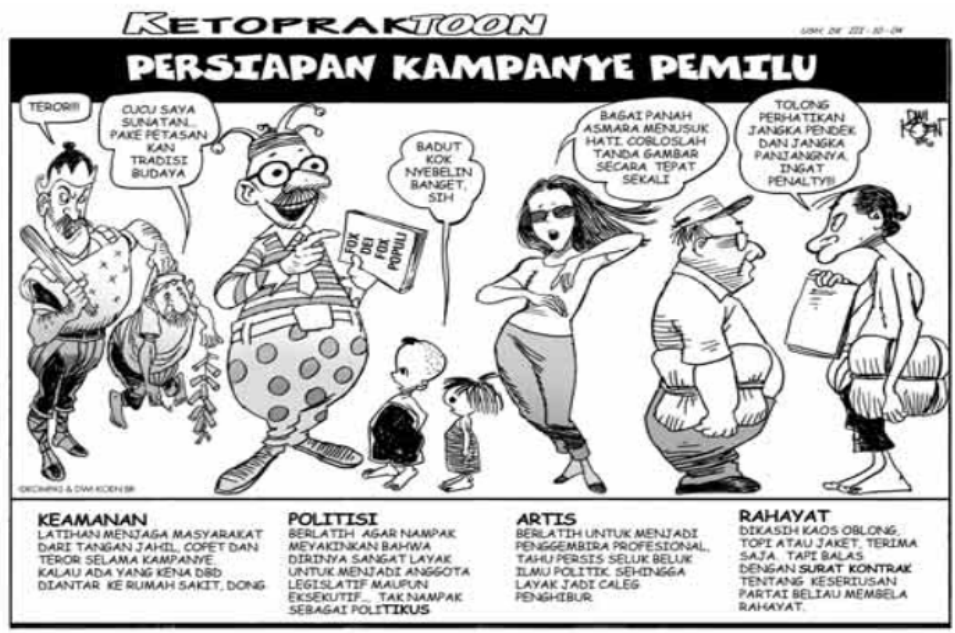

Figure 4.1: Ketopraktoon, March 1, 2004: Preparation of Election Campaign Source: Kompas Newspaper

\subsection{Code analysis}

\subsubsection{Hermeneutics code}

In comic text figure 4.1, there is a sign that politicians are depicted to be practicing in order to make sure that they are worthy of being legislative and executive members. Why politicians are depicted in clown-style clothing because their behaviour is considered funny like a clown. Clowns are people who like to joke, sometimes irrational, but they make people happy. They do not care and have no shame if they are laughed at by others, while celebrities are depicted being trained to be professional cheerleaders who know exactly the ins and outs. Why political science is so worthy of being a legislative entertainer? Artist are depicted as trying to appear convincingly by applying various ways in playing their role. Others figures are top party officials/ businessman who appears as if they are generous when dealing with commoners. They are depicted carrying a gift to be given to the people. They want to be represented with image as generous, kind and caring people.

\subsubsection{Proairetic code}

Proairetic code is a code of story, sequence, action, narrative or anti-narrative. Proairetic capability is the ability to rationally determine an action (Sosrojudho, 2008, p. 23). Overall the comic portrays a series of actions on the various elements of society ranging from security elements, politicians, celebrities, preparing in the election campaign by practicing how to make a good image, but sometimes actions and their attitudes are not rational. 


\subsubsection{Cultural code}

In the comic story, the cultural code is in the form of socio-cultural background. It is Javanese culture. There are three settings that emerged namely, culture that emerged from the political imagery, instant culture and tribute culture. Cultural code refers to the culture of capitalist society. Politicians are more concerned with 'outer image' (pencitraan) in the campaign. Imaging is done with promises using hyperbolic and utopian language. While the use of the artist in the election campaign indicated polishing, image is more important than the essence of elections, which is supposed to be a way for political education.

In Javanese politic, it is important for a candidate or politician to present himself as a figure having empathy to the have-nots and father who always protects and is able to solve problems. Politicians tend to display the image as someone who has integrity in moral, religion, education and experience. So, to meet those things, a politician often makes jargons that do not make sense. Therefore, anyone involved in politics must be able to portray himself well for the sake of gaining popularity.

\subsubsection{Symbolic code}

The symbolic code is the grouping or configuration which is easily recognizable because of regularly recurring through various textual means. Sign included in the symbolic code is a politician who dresses like a clown promoting the jargon "Vox Populi, Vox Dei,", which means "God's voice", the voice that comes from conscience. The phrase is actually contradicted by reality, where politics of vote-buying sporadically happens. This represents that the political jargon is more important in the political campaign to gain the sympathy of the masses in an instant way. A sign of the presence of an artist in a political campaign as endorser for every political party shows instantly gained popularity is important to gain the sympathy of the masses. Celebrities who play the role as politicians, who are able to entertain as well as party officials, were generous by giving donation to the people. Symbolic code succeeded to create an association of political pragmatism, especially in political campaigns. The sign a figure, such as entrepreneur or senior party official (big belly, carrying a parcel) gives the symbolic meaning of a culture of gratification. Gratification or gift is something reasonable. In the context of election, gratification in form of money and gifts to people is a symbol for the practice of money politics.

\subsubsection{Semic Code}

From the analysis of the dominant reading code, text in the image 4.1 raises the myth of the election campaign that is identical with image and money politics leading to political pragmatism. 2004 election turned out to be more pragmatic election campaign that manifests itself in the use of celebrities to boost the popularity, the use of political jargons to attract the sympathy of the masses and the protrusion of issues that take advantage of economic issues related to the improvement of the people's welfare.

Besides, political parties boosted up party members in various ways so that party members became popular, including the use of celebrities to endorse the popularity of and improve the party's image. Ironically, the artist used often did not have the background and knowledge about politics. Political parties used popularity more to exist in the world of politics, so that politics is away from the substance and essence of politics itself. Politics is more superficial. Yet, the artist did not have a background and experience in the political world.

Political languages used by the legislative candidates tended to be utopian, practical, hyperbolic and momentary. For example, the use of irrational jargons "Vox Populi Vox Dei". It means God's voice, the voice that comes from the pure conscience. Campaigns issue focused only on the politics promises. This model of campaign was dominated by issues related to the short and medium term of interests, but the long-term interests were not touched at all. In addition, the parties did not show the prominent program, which was supposed to be the most rational substance. Politicians only promoted political rhetoric rather than presenting programs and political education 
in the broad sense.

This myth is supported by the opinion of Noor (2009, pp. 43-44). Campaign activity leads more to pragmatism, so the substance is not touched. The tendency to accentuate themes of the practical needs of society, such as the issue of poverty, the issue of nine basic needs (sembako), increasing in social welfare. That issue often becomes a trade mark of the party. Promises of the campaign are often not delivered comprehensively, responsibly by showing the real steps. Candidates were often seen not ready to spell out in detail and convey the strategy in an effort to implement their promises.

Pragmatism is translated into imagery political efforts through imagery language, both verbal and nonverbal. Campaign messages were constructed so as to form a certain image desired by the candidate to influence the masses. Campaign messages put forward a political slogan than a vision, mission and programs of the party. Political pragmatism is also manifested in money politics. In the opinion of Mahadi (2011, p. 3), the political choice of the people is based on the consideration of material interests and is instant. Constituents will only vote for candidates who are able to give material rewards in form of money, goods or social aid. Politics is more transactional, causing it expensive.

Political pragmatism was also manifested during the election campaign often take advantage of the popular figures such as celebrities, to lighten up the stage and also to provoke a mass campaign to come. The condition often also leads to competition between celebrities in reaching the job, regardless the political interests of political parties contracting them. Celebrities, especially dangdut singers, often become a powerful weapon for political parties in summoning masses during the campaign. No matter what political stream, the celebrity or dangdut singer can accept the offer to perform from many political parties for the sake of money. The involvement of celebrities is not based on political platforms and political rationalization, but based on economic pragmatism which is to earn money. It also applies to the wider community who is not concerned with what the political parties means. More importantly, it is only to get money during the election campaign. In addition, the strengthening of political pragmatism is found in political decision-making based on the interests to gain power. For example, determining the sequence number of candidates is not based on a consideration of the performance of the party or candidate and track record but rather on a consideration of how much amount of money, material or social assistance that could be given by the candidates or party.

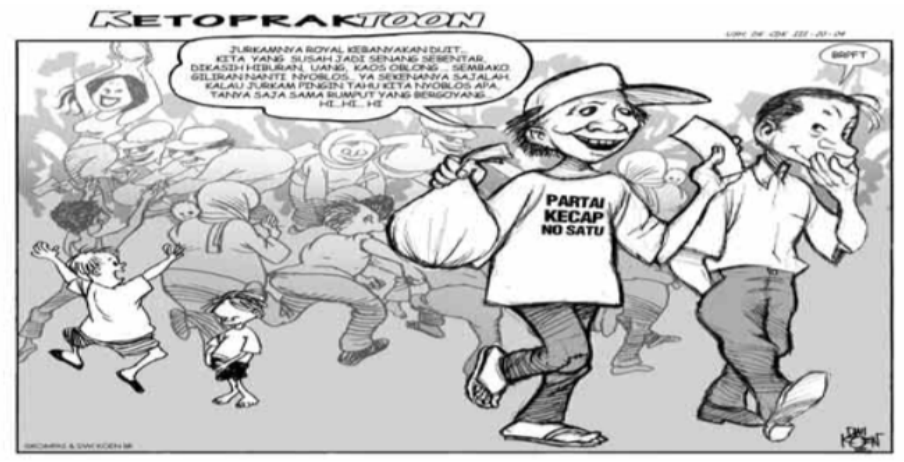

Figure 4.2: Election Campaign in Ketopraktoon March 2, 2004

Source: Kompas Newspaper

\subsubsection{Hermeneutic code}

In comic text 4.2 , it is illustrated a character of campaign participant with t-shirt saying "Ketchup Party number one", he looks happy to accept money and gifts from campaigners. Meanwhile, Pailul was amazed to see the event. The image represents that money and material thing is an important 
factor that determines the political choice of the people. On the other hand, campaigner uses people's fecklessness for political purposes.

Caption on the costume saying "Ketchup Party Number One", pointing out that all political parties are all ngecap (babbling), all campaigners also ngecap and always want to be number 1 . Ketchup Party is synonymous with political parties which like to spread political promises but show no seriousness in realization. By doing the babble (ngecap) and selling political promises, they do self-imagery.

Campaign is an event for giving away attributes and daily needs (sembako) and spending much money for most candidates. Campaign was also enlivened by entertainment in form of music and giving out campaign attributes, from t-shirts, hats, vests, etc. More shamefully, some legislative candidates handed out some money during campaign to anyone coming to the event.

\subsubsection{Proairetic code}

Proairetic code, picture of people scrambling for sembako in an election campaign and the excitement of a constituent who got parcels and envelopes when participating in an election campaign showed the material acquisition is the reason for people's political choice. Political participation is only manifested in earning rewards and based on considerations of profit and loss. The implication of this action is the emergence of money politics. Campaigners' action, distributing gifts to the participants of the campaign, leads to pragmatic and opportunist political practice from both political parties and the people.

\subsubsection{Cultural code}

In the comic, cultural code was in the form of socio-cultural background. In the comic story above, the cultural code is the political culture of Javanese society. There are two cultural settings emerging from that culture and cultural image of gratitude. Cultural code refers to a culture namely capitalist and imaginary society.

A caption saying "Ketchup Party number one" indicates that the political parties find a way to gain instant popularity and the sympathy of the people through imagery. Its effort is done by giving hyperbolic and utopian party promises, so people believe. Material reward in the form of money and sembako for constituents is a part of the efforts of political parties to influence the political choice of the people.

Meanwhile, the expression in a speech babble saying that campaigners are generous because of giving away money implies gratitude culture. Reward in form of material either goods or money is important in the change of power.

\subsubsection{Symbolic code}

Symbolic code generated through signs of the constituent costume saying "Ketchup Party number one", is the symbol of lies. Political language used by the legislative candidates tends to be utopian, impractical, hyperbolic and instant. Campaigns issue focus only on the promise - the promise of even modest political inconsistent with reality

Another symbolic code is a silhouette picture showing the campaigners, made up of celebrities, politicians and even religious leaders, distributing something to scrambling constituents implies that 2004 election campaign was marred with politics of money and shrouded by euphoric political jargons.

\subsubsection{Semic code}

2004 election campaign was identical with money politics and more concerned with imaging than giving political education for the people. Money was absolute to gain popularity, thus giving considerable amount of influence on the political choice of the people so that the candidate can achieve as many votes as possible. On the other hand, the people were pragmatic in determining 
their political choice. It indicates that people's political choice is not based on rational considerations but more on material considerations.

The sign of one of the campaigners wearing a shirt saying "Ketchup Party number one", with a happy face, carrying packages and a piece of banknotes in figure 4.2 means that people understand the meaning of the campaign and participate in political life is only pragmatic. Material thing is more important. The caption "Partai Kecap nomor satu" connotes the number one all political parties ngecap, all campaigners also ngecap and always want to be number one. Ketchup Party is identical with political parties which are royal in spreading promises but weak in its realization. By doing ngecap and selling political promises, they do self-imagery.

Comic text 4.2 raises the myth of the importance of gratification in form of goods or money to achieve the popularity and the vote of the people. Campaign is the only political euphoria for entertainment and profit. Candidates seek to build their image through the practice of money politics and political promises Campaign was enlivened by stage entertainment in the form of music added with distribution of campaign attributes ranging from t-shirts, hats, vests, etc. Even some legislative candidates handed out money to anyone who comes during the campaign. In the 2004 election, money politics was done by large and wealthy politic parties.

The practice of money politics occurring in the form of giving out sembako, preceding the voting showed that money politics had been endemic before the election, both in small and large scale ranging from sub district leader election (Pilkades) in the countryside and in the area of District/Province parliament. The rise of money politics is caused by many things, one of them is the ambitions of the politicians who want to gain power so they justify any means to gain power. On the other hand, voters were mostly classified as lower middle class, poor and oppressed, susceptible to gratitude. In addition, the Presidential Election Act only establishes a maximum limit of donation to third parties, but does not apply to presidential candidates and political parties that nominate. It allows a well-fund presidential candidate to easily obtain unlimited campaign funds without violating the maximum limit campaign contributions.

The causes of money politics are influenced by patronage culture patterns. According to Gaffar (2006, pp. 109-110), patronage culture is similar to the pattern of individualized society and ruler relationships. The relationship is reciprocal with resource exchange owned by each party. Patron as the ruling party has a variety of potential resources such as power, position, protection and resources in form of material such as (money, property, etc.). Meanwhile, the client has a form of energy resources, support, and loyalty. Patterns of relationships will be maintained as long as each party retains these resources. Patron is the party receiving the most benefit, because it has more powerful resources than the client. This pattern implies that a relationship where the businessmen/capitalists can provide support to the authorities, including funding for the activities of officials, campaign fund. These patterns of relationships will grow the practice of collusion including money politics.

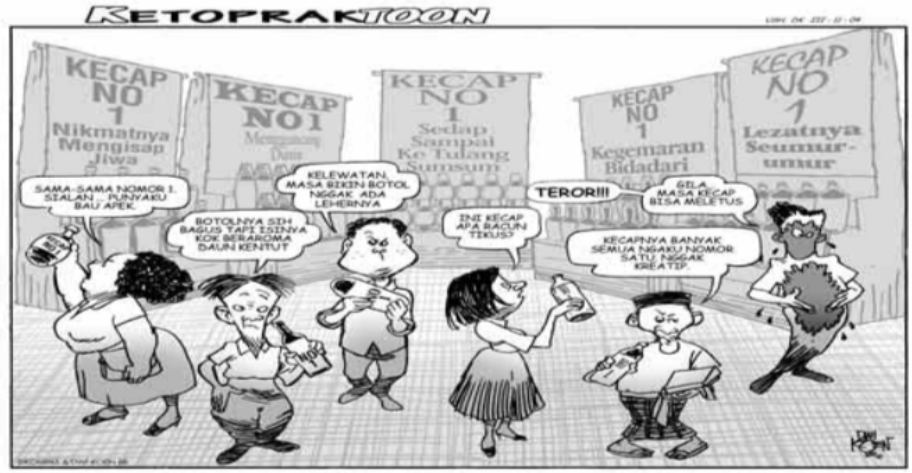

Figure 4.3: Candidates campaign, Ketopraktoon March 12, 2004

Source: Kompas Newspaper 


\subsubsection{Hermeneutic code}

Pictures in the panel show the figures of the various elements of society observing the shape and smell the contents of a bottle labeled "ketchup No. 1". Why do they observe and smell the contents of the bottle with negative facial expressions, cynically, suspiciously, angrily and disappointedly? It is because of the the political promises during the campaign were used as a means of imaging and political commodity. Political elite just built a symbolic identity, and used utopian political language that just bore political jargons. The way political elite spoke was like selling soy sauce (ketchup) or illogical.

Furthermore, the background of the image is a silhouette of a variety of posters and campaign slogans with a variety of captions. It can be interpreted that the political elites are racing to build the image and instant popularity to gain the sympathy of the society through the political promises. However, some of the promises proposed by politic parties were almost identical and no new breakthrough. Therefore, society tends to be apathetic and disappointed to see that political parties tend to vary in indulgence promises.

\subsubsection{Proairetic code}

Proairetic code is generated from the signs so it gives impact to the action. Silhouette illustrated posters and labeled ketchup No. 1 and various slogans indicate that such election campaign give the implications of the rise of political commercialization. Proairetic code is an image of five people with a cynical expression, each holding and smelling a bottle of ketchup with a negative expression while giving negative comments on each bottle implies that their actions do not believe in the political promise given by politicians during the election campaign. Political promises are considered good in packaging but smell rotten and toxic. It is merely artificial, good in packaging and polishing but full of lies.

\subsubsection{Symbolic code}

Symbolic code refers to the words "ketchup no1", meaning all political parties are claiming to be number one. Ketchup Party represents that all political parties are doing the babble (ngecap), all campaigners also ngecap and always want to be number one. Ketchup Party is identical with political parties which are royal to spreading promises but weak in their realization. To do the babbling (ngecap) and to sell empty political promises, they do self-imagery. The word "ketchup No. 1 " implies that each political party always wants to be number one and the best, but in reality, it is just nothing. Ketchup bottle symbol implies political parties or politicians, while its contents are considered as smelly and equated with rat poison meaning full of lies and contradictions

\subsubsection{Cultural code}

In the comic story, cultural code is in the form of socio-cultural background. In the comic story above, the cultural code is the political culture of Indonesian society. There are two cultural settings that emerged from that culture and cultural image of a fairy tale. The emergence of the phenomenon of the campaign containing only the political rhetoric with political promises refers to an imaginary culture of society.

\subsubsection{Semic Code}

Comic text 4.3 brings up the myth of the campaign that is only a political fairy tale. The election campaign in Indonesia puts forward political imagery to increase the popularity of presidential, vice presidential and legislative candidates. It contains only political slogan rather than vision, mission and working program of the party.

Political elite just promise likely to be less rational and only short term. Imagery politics done by the political elites and their party is to build a positive impression to the voters. They only use 
political short run strategies, in the good understanding in the short term, i.e. when in need of support vote.

In traditional thinking opportunistic politicians thinking, the public is considered being influenced by the sweet promises, so the use of utopian political language (hyperbolic and imaginary) is their choice. A famous political analyst, Arbi Sanit (personal interview, April 17, 2013), suggests that:

"... The rise of political jargon in every election campaign is not separated from the culture of Indonesian people who love to listen to fairy tales. Most of the people of Indonesia are of fairy tales lovers, like listening to oral stories, especially stories most of the content is nice. Campaign is regarded as fairy tales, having no fundamental reasons to say about something. What was said in the campaign messages is not realistic. People are easy to lull, dreaming even fall asleep, so that people are not critical enough. Why critical power does not appear in public, because they were not given the opportunity to evaluate the person who gave the political fairy tale. No information nor analytical tools, and even there is no institution, to evaluate the person. In the context of election, the electoral system does not provide time, space, and budget to evaluate the programs, activities and achievements in the political storyteller. On the other hand, the press does not give overview, background and experience of the leader candidates."

According Koirudin (2004, pp. 193-194), campaigns conducted by each presidential and vice presidential turned out to be accentuate more on figure and a symbol of a society that is still attached to the communality level. They used a charismatic figure as a symbol of the campaign, such as Gus Dur, a powerful figure of Nahdliyin, to obtain sympathy and win the vote. Another candidate, Megawati-Hashim, used religious leaders and founders of NU, K.H. Asy'ri in a poster campaign. The goal was to build an image in society that the pair is supported by Islamic group, especially among Nahdliyin. Figure symbol as a means of political legitimacy showed strong primordial in Indonesian political life. The use of religious figures as a symbol of the party in the election campaign will grow primordial attitude of society in political life which in turn can trigger fanaticism toward one pair presidential and vice candidates.

\section{Discussion and Conclusion}

\subsection{Myth Connotation Election Campaign in Panji Koming comic strip section}

Through the study of connotation to see signifier-signified associated with the socio-cultural context it acquired a number of connotations' meanings in election campaign during the Reform Era as illustrated in the following table.

\begin{tabular}{|c|c|c|c|c|}
\hline Section & Signifier & Signified & Connotation & Myth \\
\hline $\begin{array}{l}\text { Campaign } \\
\text { during } \\
\text { Reform Era }\end{array}$ & $\begin{array}{l}\text { Seeing verbal, non verbal } \\
\text { dan visual sign emerged in } \\
\text { every panel in Panji Koming } \\
\text { comic strip }\end{array}$ & $\begin{array}{l}\text { 1. Utopian and hyperbolic language } \\
\text { campaign } \\
\text { 2. The leader's language far from } \\
\text { fact and unrealistic } \\
\text { 3. Negative campaign in political } \\
\text { competition } \\
\text { 4. reward giving strategy in form of } \\
\text { money, party attribute, groceries to } \\
\text { gain constituents sympathy and } \\
\text { political choice }\end{array}$ & $\begin{array}{l}\text { 1. Election campaign only } \\
\text { contains slogans and political } \\
\text { rhetoric } \\
\text { 2. Politic party and campaign } \\
\text { constituent Pragmatism } \\
\text { 3. Irrationality of politic party } \\
\text { behavior and campaign } \\
\text { constituents } \\
\text { 4. Political symbolism rather } \\
\text { than materialistic tradition to } \\
\text { gain popularity and power. } \\
\text { 5. Primitive and traditional } \\
\text { culture in election campaign }\end{array}$ & $\begin{array}{l}\text { Campaign as } \\
\text { political rairy } \\
\text { tale }\end{array}$ \\
\hline
\end{tabular}

Kompas newspaper construction on political parties and public behavior in the election campaign during the Reform Era is not rational because people have not been able to consciously determine their political choice.

In the 2004 Elections Campaign, political parties accentuate the entertainment side, giving out money and sembako for the constituents of the campaign participants rather than providing political 
education for society. Political parties tends to be pragmatic.

In the 2004 Election, some people behaved inconsistently when they became a partisan one particular political party. People easily swung to another party considering that the party could provide greater rewards than the previous one. People's political choice was based on pragmatic considerations. Political choices were determined on the basis of material consideration. Generally, most people consider money and entertainment as the main reasons for determining political choices.

Kompas newspaper noticed primitive cultures still characterized the election campaign the Reform Era. Campaign pattern still used old fashioned ways emphasizing the power struggle between parties through marching, mainly carried out by the two major parties, namely Golkar and PDIP. Negative image about the election campaign was also demonstrated through the attitude of the people who became spectators and exploitation of political parties. Kompas also transparently highlighted negative aspects of the campaign conducted by all the political parties and presidential and vice presidential candidates. Campaign in the 2004 elections had still not provided political awareness and education for society. Politicians were imaged as clowns who could only give out sometimes unrealistic political promise.

Kompas constructed that the election campaign during the Reformation Era was only a political fairy tale. It was based on the existence of the phenomenon throughout the election in Reform Era. The candidates or party orators in many campaigns used slogans and political rhetoric. They only sold dreams through the use of hyperbolic and utopian language.

Another myth about the election found in the text was that the election campaign was mythical and only gibberish or political fairy tale. This myth emerged since the elections in the Reform Era until the election of 2004. The stigma of campaigners, politic elite and leaders who were clever at giving out political promises with the use of hyperbolic, utopian and sometimes irrational language was identical in society.

\section{References}

Ajidarma, S. G. (2011). Panji Tengkorak: Kebudayaan Dalam Perbincangan. Jakarta: Kepustakaan Populer Gramedia.

Barthes, R. ([1957] 1972). Mythologies. Translated by Annette Lavers. New York: Hill and Wang Press.

Fourie, P. J. (2008). Media Studies: Media History, Media and Society. Cape Town, South Africa: Juta and Company Ltd.

Gaffar, A. (2006). Politik Indonesia: Transisi Menuju Demokrasi. Yogyakarta: Pustaka Pelajar.

Hall, S. (1977). Representation: Cultural Representations and Signifying Practices. London, Thousand Oaks, New Delhi: Sage Publications in association with The Open University

Kaelan. (2009). Filsafat Bahasa Semiotika dan Hermeneutika. Yogyakarta: Paradigma.

Koendoro, D. (2008). Panji Koming: kocaknya zaman kala bendhu. Jakarta: Penerbit Buku Kompas.

Koirudin. (2004). Kilas Balik Pemilihan Presiden 2004: Evaluasi Pelaksanaan, Hasil, dan Masa Depan Demokrasi Pasca Pilpres. Yogyakarta: Pustaka Pelajar.

Lukens, R. J., Smith, J. J., and Coffel, C. M. (2013). Critical Handbook of Children's Literature, A, 9th Edition. London: Pearson.

Mahadi, H. (2011). "Pragmatisme Politik: Studi Kasus Proses Rekrutmen Politik PDI-P pada Pilkada, Kabupaten Sleman" in Journal of Government and Politics (JGP), Vol. 2(1), pp. 38-71. http://dx.doi.org/10.18196/jgp.2011.0004. Online access: http://journal.umy.ac.id/index.php/jsp/article/view $1168 / 423$

McCloud, S. (2001). Understanding comics: the invisible art = Memahami komik. Translated by S. Kinanti. Jakarta: Kepustakaan Populer Gramedia.

Noor, F. (2009). "Mencermati Kampanye Pileg 2009: Gradasi Peran Partai dan Gejala Pragmatisme" in Jurnal Penelitian Politik, Vol. 6(1), pp. 33-47. Online access: http://ejournal.lipi.go.id/index.php/jpp/article /view/521/329

Nurgiyantoro, B. (2004). "Sastra Anak: Persoalan Genre" in Humaniora, Vol 16(2), pp. 107-122. Online access: http://download. portalgaruda.org/article. $p h p ?$ article $=3067 \& \mathrm{val}=297$

Pujiyanto. (2008). Teknik Grafis Komunikasi Jilid 2 untuk SMK. Jakarta: Direktorat Pembinaan Sekolah Menengah Kejuruan, Direktorat Jenderal Manajemen Pendidikan Dasar dan Menengah, Departemen Pendidikan Nasional.

Sastriyani, S. H. (2004). "Studi Gender dalam Komik-komik Prancis Terjemahan" in Humaniora, Vol. 16(2), pp. 
123-132. https://doi.org/10.22146/jh.v16i2.812. Online access: https://journal.ugm.ac.id/jurnalhumaniora/article/view/812/654

Sosrojudho, A. A. (2008). Propaganda pemimpin politik Indonesia: mengupas semiotika Orde Baru Soeharto. Jakarta: LP3ES

Sturken, M. and Cartwright, L. (2001). Practices of Looking: An Introduction to Visual Culture. Oxford: Oxford University Press

\section{Newspaper}

Kompas, Ketopraktoon, March 1, 2004

Kompas, Ketopraktoon, March 2, 2004

Kompas, Ketopraktoon, March 12, 2004 